University of Nebraska - Lincoln

DigitalCommons@University of Nebraska - Lincoln

To Improve the Academy

Professional and Organizational Development

Network in Higher Education

1997

\title{
A Global Faculty Development Network: The International Consortium for Educational Development (ICED)
}

Karron G. Lewis

Eric Kristensen

Follow this and additional works at: https://digitalcommons.unl.edu/podimproveacad

Part of the Higher Education Administration Commons

Lewis, Karron G. and Kristensen, Eric, "A Global Faculty Development Network: The International Consortium for Educational Development (ICED)" (1997). To Improve the Academy. 382.

https://digitalcommons.unl.edu/podimproveacad/382

This Article is brought to you for free and open access by the Professional and Organizational Development Network in Higher Education at DigitalCommons@University of Nebraska - Lincoln. It has been accepted for inclusion in To Improve the Academy by an authorized administrator of DigitalCommons@University of Nebraska - Lincoln. 
Lewis, K.G., \& Kristensen, E. (1997). A global development network: The international consortium for educational development. In D. DeZure (Ed.), To Improve the Academy, Vol. 16 (pp. 53-60). Stillwater, OK: New Forums Press and the Professional and Organizational Development Network in Higher Education. Key Words: Academic Proparalion, Career Development, Conferences, Faculty Development, Networking, Organizational Development, Research, Student Evaluation of Instructor Pefformance, Teaching Methods.

\section{A Global Faculty}

Development Network: The International Consortium for Educational Development (ICED)

\section{Karron G. Lewis}

The University of Texas at Austin

\section{Eric Kristensen}

Berklee College of Music

Although higher education systems around the world differ considerably in structure and the methods used in teaching, there is universal concern for the quality of undergraduate teaching and learning. Thus, faculty and educational development activities are a worldwide phenomena. In 1993, The International Consortium for Educational Development (ICED) was born to facilitate exchange of faculty and educational development information. This article looks at the history of ICED and the accomplishments of this organization since its inception. We look at examples of faculty development work in Sweden, Australia and Finland and consider the implications these 
international programs might have for faculty developers and faculty development work in the U.S. and Canada.

While higher education systems around the world differ considerably in structure and employ a rich variety of methods, there is a universal concern for the quality of undergraduate teaching and learning in the face of declining resources, increased student numbers and the diversity of students. In many countries with developed higher education systems, there are a range of national and regional organizations, such as POD, for sharing expertise and best practice. There is, however, relatively little international sharing, and countries with less well-developed higher education systems often have very poor access to expertise.

\section{The Birth of ICED}

To facilitate international sharing of expertise for the improvement of teaching and learning, the International Consortium for Educational Development in Higher Education (ICED - pronounced eye-sed) was formed in Oxford, England in 1993. The Consortium provides a basis for networking and other forms of cooperation and collaboration among those with a responsibility for faculty/educational development. The aim is not to duplicate the role of existing national and regional networks but to supplement them through international links. In particular, the Consortium goals are to:

1. improve, through sponsored research, professional practice in higher education teaching;

2. promote, through training and publications, the dissemination of relevant research about teaching and learning to practicing teachers in higher education;

3. provide, through symposia and conferences, a forum for the discussion of significant and emergent teaching and learning issues in higher education worldwide;

4. facilitate, through exchanges and opportunities for cooperative ventures, the professional development of those working as educational developers in higher education worldwide; and 
5. promote, through meetings and interchange of information, cooperation and liaison among national and international networks, groups and associations with complementary purposes and activities. (Gibbs, 1995)

The Consortium Council consists of presidents (or their representatives) of national and regional educational development organizations such as POD. At the first meeting, organizations from six countries were represented. At the 1996 ICED Council meeting, representatives from 16 organizations in 14 countries attended; other networks are being contacted and invited to join. (A list of participating organizations is given in the Appendix.) POD is one of the original member organizations and has been active since 1993, sending a representative to each Council meeting.

At its annual meetings, the ICED Council members share information about their faculty development networks and how they function, discuss issues related to nurturing member networks, raise issues that are of concern to higher education teaching and learning, and brainstorm ways to encourage and assist developing networks. Each council member also brings material from their network to display. As representatives of POD, we took copies of To Improve the Academy, Teaching Excellence, and the Handbook for New Practitioners. It has been very enlightening to hear what others are doing and comforting to know that many of the challenges faced by the POD Network and our individual faculty development programs are also faced by many others around the world.

\section{ICED Accomplishments}

In its short life span, the Consortium, under the leadership of Graham Gibbs of the Open University in England, has accomplished a great deal toward achieving the organization's goals (see above).

First, the inaugural issue of the International Journal of Academic Development has been published by Kogen Page of London. It includes articles on best practice, starting new faculty/educational development units, and promoting learning. Practitioners from around the world are encouraged to submit articles for publication. Subscrip- 
tions may be acquired through the POD Network at substantial savings.

Second, a World Wide Web page has been established (DeLiberations on teaching and learning in higher education http://www.lgu.ac.uk/deliberations/ ) from which information about all participating networks can be obtained and from which topic-based information about educational development practices and exemplary teaching and learning strategies can be accessed.

Third, ICED has initiated sponsorship for biennial international conferences. The first such conference was held in Vasa, Finland, in June 1996 to facilitate sharing of expertise and to create a venue for faculty developers from around the world to meet each other face-toface. The theme of this first conference was "Improving University Teaching" and the conference brought together 90 faculty developers from 32 different countries. These developers presented papers and conducted workshops on topics such as:

- 'The relationship between university lecturers' qualifications in teaching and student ratings of their teaching performance" (Australia)

- "A compulsory pedagogic course to become an Associate Professor" (Sweden)

- "Self-evaluation: a strategy for preparing teaching staff" (South Africa)

- "Valuing Teaching: Moving beyond rhetoric in Hong Kong tertiary institutions" (Hong Kong)

Dr. Wilbert McKeachie presented one of the keynote addresses for the conference. Abstracts for all of the papers presented at this conference are available at:

http://www.lgu.ac.uk/deliberations/teachers/abs_ind.html The abstracts were put on this web location prior to the conference so participants could read them and correspond with the authors to ask questions or receive a complete copy of the paper. The language of the conference was English and there was a great deal of sharing and networking that occurred outside the sessions.

The next ICED Conference will be held in Austin, Texas, U.S.A. in April 1998. The theme for this conference is "Supporting Educational, Faculty \& TA Development Within Departments and Disci- 
plines." For information about this conference, contact Karron Lewis at kglewis@mail.utexas.edu.

ICED Projects that are still being developed include:

1. the publication of the International Yearbook of Educational Development Services. In this yearbook, each of the participating networks will be listed along with individual Faculty/Instructional/Educational Development Centers and Programs.

2. the establishment of a pool of experienced faculty/educational developers who would be willing to consult with developing networks. Graham Gibbs has already done some of this in Spain and discussions are beginning with some of the Baltic countries.

\section{Some Interesting Papers and Sessions at the ICED Conference}

While many of the faculty/educational development programs around the world are very similar in scope and depth to those currently offered in most U.S. centers, we were struck by the overriding theme of "mandatory courses/programs" that are springing up in many countries. In reaction to a lack of pedagogical training for faculty members in higher education, governments and other governmental agencies are pushing to incorporate such training in preservice or inservice programs. "There is currently a debate in the UK, initiated by the Association for University Teachers, about the desirability of professionalizing university teaching with national standards and formal requirements for initial training. There is already a national accreditation scheme in the UK, with $25 \%$ of higher education institutions voluntarily signed up." (Gibbs, 1995, p. 2) Some certification courses require $200+$ hours of instruction. (See the Oxford Brookes University course requirements for a Certificate in Teaching at: http://www.lgu.ac.uk/deliberations/teachers/cguide.html )

To give you an idea of issues discussed at the ICED Conference, we've summarized several of the papers and presentations below.

\section{Sweden}

In Sweden, Bengt Ekman reported that faculty members who wish to become Associate Professors ("docents") at the Swedish University 
of Agricultural Science must complete a total of eight weeks of pedagogical courses. All teachers go through a four-week course just after they are hired, but those who wish to become Associate Professors must attend an additional four-week course. The contents of the second four-week course include: communication, speaking-writing for the general public, relations between people, learning and teaching in theory and practice, the lecture as a pedagogic phenomenon, how to give good directions, pedagogic studies of one's own discipline, and course literature (Ekman, 1996).

\section{Australia}

Max Gillett, from the University of Wollongong in Australia, conducted a study to determine whether faculty members who have had pedagogical training (e.g., formal degrees or accredited training courses in education or teaching) receive higher ratings from their students. Of the faculty who participated in the study, 91 held qualifications and 84 did not. The students responded to a 23-item survey for both groups and significant differences were found. Max concluded that, "These results indicate that academics with qualifications in teaching were perceived by students to be significantly superior teachers than those without qualifications. This holds implications for the selection and professional development of academic staff for universities in their quest to improve the quality of teaching. It also justifies the expenditure of resources on special programs for improving tertiary teaching and providing university staff with suitable qualifications in teaching and education" (Gillett, 1996).

\section{Finland}

Another fascinating study was reported by Merja Vanhala from the University of Oulu in Finland. This study looked at the norms for interaction between students and lecturers in classrooms in various disciplines. The study concentrated on large classes $(n=129)$ which are most common in beginning university studies. Some of the findings were:

Faculty of Humanities. There was complete silence in the classroom; no interaction between students and lecturer. Questions asked 
by lecturers were usually thetorical. Handouts were not used, so students took notes. These students typically came to class on time and did not leave before the end of the lecture.

Faculty of Education. There was a lot of interaction between students and the lecturers. Lecturers seemed very interested in the students and their questions and opinions and the students participated readily. Sometimes, especially at the beginning of the lecture, the students were somewhat noisy.

Faculty of Science. Some of the lecturers showed quite negative opinions of the students. They typically did not like students to ask questions or comment on the content. Most of the students just listened quietly. There was a certain "distance" between the lecturers and students.

Faculty of Medicine. The students in these classes seemed to appreciate the lecturer's knowledge about the subject, but some students rudely disturbed the class because they didn't like the way the lecturer was teaching. Some lecturers also behaved quite rudely because they didn't want to answer students' questions.

Faculty of Technology. The lecturers in this discipline typically had carefully prepared lecture material (e.g., overheads, handouts). No one asked questions in class. The students came in and out of the classrooms as they pleased and quite often spoke to each other, disturbing the lecturer. The lectures seemed to be like social events for the students.

It was documented that both lecturers' and students' attitudes seemed to have a significant affect on each other. If the lecturer was indifferent, the students were too. A course was subsequently developed to help faculty teach these large classes more actively and effectively (Vanhala, 1996).

\section{What Can Be Gained by Participation in an International Consortium?}

From some of the examples mentioned above (the accreditation of university teachers, for example), one can see that the world at large takes a somewhat different view of faculty development theory and practice than those generally shared by POD members in the U.S. and 
Canada. These differences can help us not only to broaden our own perspective on our work, but can also provide an opportunity for fascinating critical reflection on assumptions and theoretical frameworks, explicit and implicit, that are embedded in our practice.

As an example of the possibilities inherent in this critical reflection is Graham Gibbs' paper, 'Preparing University Teachers: an International Overview of Practice and Issues," presented at the 1996 Improving University Teaching conference in Nottingham, England. In this comparative vignette of faculty/educational development practices in Australia and the U.S., he discusses eight aspects of practices and how they differ. These eight aspects include the following characteristics: program participants, numbers, timing, scale, focus, theoretical base, typical activity or activities, and some typical variations on these. activities.

According to Gibbs, the typical U.S. program's participants are teaching assistants; their numbers are large; they typically go through these programs as part of preservice training; the time scale is short (fewer than ten hours); the focus is classroom practice, teaching, and the improvement of conventional practice; the theoretical base is behavioral and cognitive; and typical activities include a workshop on communication skills with variations such as a lead TA program. ${ }^{1}$

In Australia, Gibbs sees the following contrasting characteristics: Australians tend to design faculty development programs in which participants are lecturers (faculty), in small numbers and as part of a long (more than two hundred hour) inservice training program; the focus of their programs is on reflective practice, learning and the development of new practice; the theoretical base is phenomenological (understanding the university as an educational system); characteristic activities include teaching portfolios and a research project and variations include a management (administrative) strand (Gibbs, 1996).

\footnotetext{
'In some programs, one TA in each department receives additional training (and often an increased stipend) in order to become a "lead" TA. This lead TA then organizes development activities for his/her peers, in conjunction with the central teaching and leaming center. There are variations on this model in TA development programs around the U.S.
} 
The picture presented in this vignette comparison between Australian and U.S. practices gives one a flavor of the interchange possible in an international faculty/educational development setting. We work in different educational systems, in different institutional contexts within vastly different political, economic and social structures. The educational systems of countries outside the U.S. feature various degrees of central funding and control. However, the issues faced by faculty developers in those countries, where politicians are looking at the economics of higher education and examining the productivity of higher education faculty, are not that far removed from the faculty developer facing many of the same issues at a large state institution in the U.S.

The clear trend emerging from Europe, Australia and southeast Asia indicates that compulsory training for new faculty members in the context of a long, in-service program over a number of years is becoming a norm for those systems. The certification of university teaching is a lively issue in ministries of education all over northern Europe. Will our state legislators, when they hear of these developments, be far behind? We can learn a great deal from our colleagues around the world, and we have much to offer them. In the exchange of information and ideas, we improve the practical and theoretical basis of our work as a profession, and will learn to grow together to meet the demands of new economic and social realities.

Another, concomitant trend concerns itself with the certification of faculty/educational developers. The Staff and Educational Development Association (SEDA) in the UK has done groundbreaking work on developing and implementing a national certification program for faculty/educational developers. Their work has already stimulated fundamental discussions among the members of POD's governing body (the Core Committee) and its Professional Development subcommittee concerning the competencies and skills necessary to the faculty development profession in the U.S. and Canada. POD is a long way from becoming a professional accreditation association, but these discussions, sparked by the work of our colleagues in England, have been lively, deep and serious. 


\section{What Lies Ahead?}

It is clear that POD members are already involved in international work. Of the attendees at our session in October 1996, seven members reported having worked or visited with faculty developers in Australia, China, England, France, Germany, Hong Kong, India, Italy, Japan, Hungary, Malaysia, Mexico, the Netherlands, New Zealand, Switzerland, Taiwan and Thailand. Many more colleagues from overseas visit our programs here in the U.S. and Canada. Some countries have well-established faculty development programs and networks and have generated a significant body of practical and theoretical knowledge. Faculty developers and faculty development networks in these countries have an obligation to support international colleagues in countries where faculty development knowledge and practice are just now emerging.

The ICED Council and the international conferences that it will sponsor will allow this fertile exchange to flourish. The Council has as one of its stated aims to support and encourage the development of national or regional networks in parts of the world not currently served by any such organization. The conferences will be an inspiring forum for the exchange of practical knowledge and educational development research from all around the world. For many of us old, seasoned hands, the exposure to colleagues just learning about and entering the field in a country where these ideas are new and exciting should be inspiring. Likewise, the opportunity to have one's assumptions vigorously challenged by experienced colleagues in other countries is exhilarating and thought-provoking.

To conclude, the possibilities for developing the theoretical and practical underpinnings of our profession are greatly enhanced by the exchanges possible in an international context. POD's involvement in international work, both informally by its members and formally through its association with ICED, will allow the faculty development profession to grow and mature in many institutions, systems, countries and regions around the world. 


\section{References}

Ekman, B. (1996, June). Compulsory pedagogical training as a requirement for an associate professorship. Paper presented at the 1996 ICED Conference, Vasa, Finland. (Bengt.Ekman@cf.slu.se)

Gibbs, O. (1995, March). ICED: International Consortium for Educational Development in Higher Education - executive summary. Summary of ICED Council Meeting in Dunchurch, England. (gpgibbs @ brookes.ac.uk)

Gibbs, G. (1996, July). Preparing university teachers: An international overview of practice and issues. Paper presented at Improving University Teaching conference, Nottingham University, UK.

Gillett, M., Nast, A., \& Booth, E. (1996, June). The relationship between university lecturers' qualifications in teaching and student ratings of their teaching performance. Paper presented at the 1996 ICED Conference, Vasa, Finland. (Max_Gillett@uow.edu.au)

Vanhala, M., Kokkoniemi, T., Kulmala, S., \& Ryhänen, H. (1996, June). The ethics of lecturing: Can we find some moral norms for interaction between students and a lecturer behind the classroom doors? Paper presented at the 1996 ICED Conference, Vasa, Finland. (Merja.Vanhala @ koivu.oulu.fi)

Contacts:

Karron G. Lewis

Center for Teaching Effectiveness

The University of Texas at Austin

Main Building 2200 (G2100)

Austin, TX 78712-1111 USA

(512) 232-1776

(512) 471-0596 FAX

kglewis@mail.utexas.edu

\section{Eric Kristensen}

Faculty and Instructional Development

Berklee College of Music

1140 Boylston Street

Boston, MA 02215-3693

(617) 747-2229

(617) 262-3083 FAX

ekristensen@berklee.edu

Karron G. Lewis is the Assistant Director of the Center for Teaching Effectiveness and TA Program Coordinator at The University of Texas at Austin. She is a past President of the Professional and Organizational Development Network in Higher Education and has served as the POD Network representative to the ICED Council 
since 1995. She is the Conference Coordinator for the ICED Conference to be held in Austin, Texas in April of 1998.

Eric Kristensen is the Director of Faculty and Instructional Development at Berklee College of Music in Boston, MA. He is the current President of the Professional and Organizational Development Network in Higher Education and has served as the POD Network representative to the ICED Council since 1996. 


\section{Appendix}

\section{ICED Participating Organizations}

Australia, New Zealand and Southeast Asia

HERDSA - Higher Education Research and Development Society of Australasia

Belgium

CgAO - Contactgroep Academisch Onderwijs (Flemish-speaking Universities)

Canada and United States

STLHE - Society for Teaching and Learning in Higher Education

POD - Professional and Organizational Development Network in Higher Education

Denmark

DUN - Dansk Universitetspedagogisk Netverk

Finland

EDUC-net and PEDA-forum (e-mail networks)

Germany

AHD - Arbgeitsgemeinschaft f 1 Hochschuldidaktik e.V.

Holland

CRWO - Contactgroep Research Wetenschappelijk Onderwijs India

NetSED - Network for Staff and Educational Development

Norway

PEDNETT

South Africa

SAAAD - South African Association for Academic Development Spain

Universitat Politecnica de Catalunya

Sweden

SWERDHE

Switzerland

Informal network of educational developers 


\section{UK}

SEDA - Staff and Educational Development Association

HEQC - Higher Education Quality Council

OCSD - Oxford Centre for Staff Development

Networks which have shown interest in ICED but have not yet sent representatives to Council meetings:

\section{France}

ADMES - Association pour le Développement des Méthodes de formation dans l'Enseignement Supérieur (France)

AIPU - Association Internationale de Pédagogie Universitaire (International association for French-speaking universities in Europe, North America, Africa)

Austria

OeGHD - Oesterreichische Gesellschaft fuer Hochschuldidaktik 